study programmes and the materials neces- ary, Strathclyde, University, Glasgow. Details sary for them, is guided by an academic of both events are obtainable from the execucouncil under the chairmanship of $\mathrm{Sir}$ tive secretary, Biochemical Society, 7 Warwick Brynmor Jones. Further details are avail- Court, Holborn, London WCIR 5DP. (Tel. able from the director of the department, B.M.A. House, Tavistock Square, London WC1H 9JP.

\section{New Chairman of J.C.C.}

Sir Kenneth Robson has been elected Chairman of the Joint Consultants Committee, to succeed Sir John Richardson. Sir Kenneth is Registrar of the Royal College of Physicians and had been Joint Secretary of the J.C.C. for over 10 years. Mr. A. Parker, a consultant surgeon from the London Hospital,

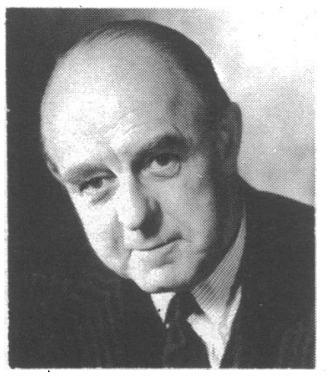
was elected to replace Sir Kenneth and join Dr. D. Stevenson, Secretary of the B.M.A., as Joint Secretary.

\section{Royal College of Pathologists}

At the ninth annual general meeting of the college held on 21 November the following honorary officers were elected: president, Professor J. V. Dacie, F.R.S.; vicepresidents, Professor D. N. Baron, Dr. A. J. McCall, Professor R. A. Shooter; registrar, Professor R. C. Curran; treasurer, Professor R. D. Teare; assistant registrar, Dr. B. S. Cardell.

\section{Pests in Laboratories}

The Medical Research Council has published a soft-covered handbook, Common Parasites of Laboratory Rodents and Lagomorphs, which gives advice on the identification of parasites, diagnosis of illness due to them, and its treatment. The book, which is printed on gloss paper with many half-tone illustrations, is published by H.M.S.O. price $£ 3.00$.

\section{Seminars at B.M.A. House}

A seminar on "Homosexuality" will be held at B.M.A. House, London, on Friday, 15 December, from 10 a.m. to 5 p.m. For details see advertisement on page xiv.

\section{People in the News}

Dr. F. H. C. Crick has been awarded a Royal Medal by the Royal Society "in recognition of his elucidation of the structure of DNA and his continuing contribution to molecular biology."

Dr. R. G. Whitehead, director of the Medical Research Council Child Nutrition Unit, Mulago Hospital, Kampala, Uganda, has also been appointed director of the Dunn Nutritional Laboratory, Cambridge, from October 1973.

\section{COMING EVENTS}

Biochemical Society-Meetings, (1) 18-19 December, Nottingham University; (2) 4-5 Janu-
01-242 1076.)

Royal Society of Medicine-Holiday lectures suitable for young people between ages of 13 and 19 on 1, 3, 5 January, 2.30 p.m. Details and tickets (free) are obtainable from the conference secretary, R.S.M., 1 Wimpole Street, London W1M 8AE. (Tel. 01-580 2070.)

Southampton and District Occupational Health Advisory Conncil-Day symposium, "Asbestos," 4 January, 9.15 a.m., Southampton College of Technology. Details and application forms are obtainable from Mrs. Jean Forfitt, 224 Winchester Road, Southampton, Hants.

Biological Engineering Society-Conference, "Education, Training and Careers in Biomedica Engineering," 5-6 January, London W.C.1. Details and registration forms from Dr. O. C. J Lippold, department of physiology, University College London, Gower Street, London W.C.1.

\section{SOCIETIES AND LECTURES}

For attending lectures marked * a fee is charged or a ticket is required. Applications should be

Monday, 4 December

INSTITUTE OF LARYNGOLOGY AND OTOLOGY.-5.30 p.m. Clinicopathological conference by Professor 1 .
Friedmann.

Royal Postgraduate Medical School.-4 p.m. Dr. A. S. Tavill: Metabolism of Plasma Proteins.

\section{Tuesday, 5 December}

ROYAl COLlege OF SURGEONS OF ENGLAND. - 5 p.m. Arnott demonstration by Professor C. Long: Be Presence of Calcium Ions. Tuesday 12 December on channel 1. Medicin Today: Diabetes in Pregnancy.

\section{Wednesday, 6 December}

CARDIOTHORACIC INSTITUTR.-At Institute Pearson:
Radiological Procedures and the Clinician. INSTITUTB OF NeUROLOGY.-6 p.m., Dr. A. Ridley:
Glioma Immunology; 7 p.m., Mr. J. S. Garfield: Glioma Immunology; 7 p.m., Mr. J. S. Garfield: Aspects of Treatment of Gliomas.
INSTITUTE OF UROLOGY. 5 p.m., Mr. J. E. A. Wickham Surgery of Urinary Calculi.

Surgery of Urinary Calculi.
LONDON UNIVERSITY. - At Institute of Child Health, 5.30 p.m., Professor A. E. Boyo (Lagos): Haemaglobulin Biochemistry and Erythrocyte Pathology gl orulin Biochemistry and Erythrocyte Pathology.
Litchfield lecture by Mr. C. Webster: Medicine in the Litchfield lecture by Mr. C. Webs

ROYAI COLLEGE OF SURGEONS OF ENGLAND.-4.30 p.m. Brent: Tolerance and Transplantation.

Thursday, 7 December DUNDER UNrversiry.- 5 p.m. Dr. T. A. Sears: Neuro-
physiological aspect of Voluntary Activation of Respiratory Muscles.

Infirmary 5 p.m. Infirmary, 5 p.m., Professor C. T. Dollery: Is there Rational Basis for Drug Therapy ?
RoYal ColLBGB OF PHYSICIANS OF LONDON. -8.30 p.m. Fitzpatrick lecture by Dr. E. A. Underwood: Evolution of Haematology-History of some Diseases of the Blood

ROYAI COLIFGe OF SURGgons of ENGLAND. -5 p.m. McIndoe lecture by Dr. J. Bruner: Contributions of Sir Archibald McIndoe to Surgery of the HandSurgical Exposure of Flexor Tendons in Surgery of
the Hand. Royal Postgraduate Mrdical School.-6 p.m. Dr. M. Rosen: Some Problems on Pain Relief in ST. MARY's Hospital MEDICAI SCHOOL. -5.15 p.m.
Professor E. M. Symonds: Medical Responsibility in Professor E. M. Symonds: Medical

Friday, 8 December

LONDON UNIVERSITY.-At St. Bartholomew's Hospital Medical College, 5 p.m., Dr. M. M. Elkind (New York): Damage-repair Studies of Sublethal Radiation and Drug Effects in Mammalian Cells.

ROYAI COLLEG OF SURGEONS OF EDINBURGH.-4.30 p.m., Professor B. N. Brooke: Current Problems in Management

Royal Postgraduatr Medical School.-11 a.m., Surgeon Vice-Admiral J. Watt: Burns of Sea Battles.

\section{Sunday, 10 December} made first to the institution concemed. Erasmus Wilson demonstration by Professor $\mathrm{L}$

T. ANDREw's HOSPITAL, LONDON B.3.-1 p.m., M

MANCHESTER ROYAL INFIRMARY.-10 a.m., Dr. T.

\section{UNIVERSITIES AND COLLEGES}

\section{ABERDEEN}

Appointments.-Dr. R. Jenkins Taylor (lecturer, and gynaecology); Dr. P. E. G. Carter (medical officer, and gynaecology); Dr. Pealth Service).

LONDON

M.D.-D. J. Coltart, A. B. Shaw, R. S. Stern, D. R M.S.-J. E. Castro.

M.S.-J. E. Castro. Cooke, J. Caldwell, T. Thane, S. R. Hesselwood, S. O. Wilt,

M.Sc. - In the Faculty of Medicine: Sher M. Khan, A. H. Mian, Pushpa Sadanah, Jean O. Wi'liams,
P. J. Ell, J. G. B. Millar, E. D. Yurman, Violeta M. Manansala, J. Reeve, B. J. Essex, W. M. Garraway, Martini, Judith Robinson, Gioria G. Ruocco, J. A. Spies. sourian.

ROYAL COLLEGE OF SURGEONS IN IRELAND F.R.C.S.I.-H. C. Bredin, D. R. Edwardes, P. R. Gafney, S. P. F. Hughes.

\section{APPOINTMENTS}

East Anglan Regional Hospital Board.-Mr. W. B Costley (consultant in obstetrics and gynaecology, Grea Yarmouth and Lowestoft areas); Dr. M. J Brindle North Cambridgeshire H.M.C.); Dr. E. B. Peterson (consultant in child and family psychiatry, Peterborough and Stamford H.M.C.); Mr. R. Martin (consultant in Obstetrics and gynaecology, Norfolk and Norwich areas); borough and Stamford H.M.C. and Fulbourn and Ida Darwin H.M.C.); Dr. J. MacNae (consultant in acciden and emergency, Norfolk and Norwich Hospital).

SOUth-western Regional Hospitai. Board.-Dr. A. D. Dr. F (consultant physician, Cornwall clinical area) area (consultant general surgeon, North Gloucestershire clinical area); Mr. R. J. Clarke (consultant general surgeon, South Somerset clinical area, Yeovil); Dr. J. S. Watkins (consultant geriatrician, Devon and Exeter clinical area); Dr. F. X. M. Beach (consultant in general medicine, South Somerset clinical area, Yeovil); Dr. clinical area); Dr. Margaret T. McKiddie (consultant in general medicine, North Gloucestershire clinical area) Dr. Lorna A. Brown (consultant anaesthetist, Bath clinical area); Dr. G. D. Morrison (consultant Venereologist, Plvmouth and Devon and Exeter clinical areas); Exeter clinical area); Dr. B. W. Perriss (consultan anaesthetist, Devon and Exeter clinical area); Dr. D. H Keeling (consultant in nuclear medicine, Plymouth and

\section{Correction}

Protection against Hong Kong Influenza

In the letter from Dr. R. E. Hope-Simpson (25 November, p. 490), in the fourth line of the second paragraph and in the accompanying Table, the term " 'Asian' $\mathrm{H}_{3} \mathrm{~N}_{2}$ virus" should have read " 'Asian' $\mathrm{H}_{2} \mathrm{~N}_{2}$ virus."

\section{Notice to Authors}

When original articles and letters for publication are not submitted exclusively to the British Medical fournal this must be stated. Accepted articles may subsequently be selected for publication in the North American monthly edition.

Correspondence on editorial business should be addressed to the Editor, British Medical fournal,

B.M.A. House, Tavistock Square, London WCIH 9JR. Telephone: 01-387 4499. Telegrams : Aitiology, London, W.C.1.

Authors wanting reprints of their articles should notify the Publishing Manager, B.M.A. House, Tavistock Square, WCIH 9JR, on receipt of proofs.

\section{(C) British Medical Journal 1972}

All Rights Reserved. No part of this publication may be reproduced, stored in a retrieval system, or transmitted, in any form or by any means, electronic, mechanical, photocopying, recording or otherwise, without the prior permission of the British Medical fournal. 